and D. George (eds.)

\title{
Distribution patterns of Terebellidae (Annelida: Polychaeta): an application of Parsimony Analysis of Endemicity (PAE)
}

\author{
ANDRÉ RINALDO SENNA GARRAFFONI ${ }^{1,2}$, SILVIO SHIGUEO NIHEI $^{1}$ \\ and PAULO DA CUNHA LANA ${ }^{1}$ \\ ${ }^{1}$ Centro de Estudos do Mar, Universidade Federal do Paraná, Av. Beira mar s/n, CP 50002, Pontal do Paraná, PR, Brazil, \\ 83255-000, E-mail: garraffoni@ufpr.br \\ ${ }^{2}$ Curso de Pós-Graduação em Ciências Biológicas, Zoologia, Universidade Federal do Paraná, Setor de Ciências \\ Biológicas, Departamento de Zoologia, Curitiba, Brazil.
}

\begin{abstract}
SUMMARY: The biogeography of Terebellidae (Polychaeta) using Parsimony Analysis of Endemism (PAE) is investigated and species and genera distribution in relation to coastal and continental shelf areas of endemism around the world is considered. Hierarchical patterns in PAE cladograms are identified by testing for congruence with patterns derived from cladistic biogeography and geological evidence. The PAE cladogram indicates that many of the extant terebellid worms from the current Southern Hemisphere ("Gondwanan clades") have originated from Laurasian ancestors or, in the case of the clade formed by Brazilian, South Atlantic and Antarctic taxa, have descended directly from an ancestral lineage common to some Northern areas. The present analysis also shows a high level of endemism at the species level. Relationships of the areas differ slightly from previous biogeographical analyses applied to other polychaete families.

Keywords: marine biogeography, historical biogeography, areas of endemicity, Terebellinae, Polycirrinae, Thelepodinae, Trichobranchinae.

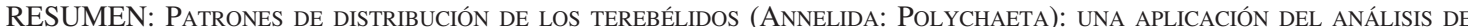
PARSIMONIA DE ENDEMICIDAD (PAE). - Se presenta la biogeografía de la familia Terebellidae (Polychaeta) usando Análisis de Parsimonia de Endemismos (PAE). En el estudio se considera la distribución de las especies y géneros en relación a endemismos de costas y plataformas continentales a escala planetaria, Los patrones jerárquicos en los cladogramas del PAE se identifican comprobando su congruencia con patrones obtenidos de biogeografía cladística y evidencias geológicas. Los cladogramas obtenidos en el PAE indican que muchas de las formas extintas de gusanos terebélidos procedentes el actual Hemisferio Sur ("cladogramas Godwana") tienen su origen en ancestros de Laurasia o, en el caso del cladograma formado por los taxones Brasileños, del Atlántico Sur y Anárticos, descienden directamente de una línea ancestral común a algunas áreas del Norte. El presente estudio muestra asimismo un alto nivel de endemismo a nivel de especies. Las relaciones obtenidas para las áreas estudiadas son un poco diferentes cuando se comparan con trabajos previos realizados en otras familias de poliquetos
\end{abstract}

Palabras clave: biogeografía marina, biogeografía histórica, áreas de endemicidad, Terebellinae, Polycirrinae, Thelepodinae, Trichobranchinae.

\section{INTRODUCTION}

Biogeographic studies have two distinct stages, a first stage based on a conjecture on a common history, that means that different taxa are integrated in space and time (primary biogeographic homology), and a second which refers to the cladistic testing of the previously hypothesized homology or secondary biogeographic homology (Morrone, 2001). Panbiogeography tries to identify primary biogeo- 
graphic homologies, whereas cladistic biogeography deals with secondary biogeographic ones.

An alternative cladistic approach which also allows for the elucidation of faunal distribution patterns using biota similarity is the Parsimony Analysis of Endemicity (PAE). PAE, like cladistic analysis, is based on the a priori assumption that the ingroup is monophyletic (Cracraft, 1991). Geographic areas are treated as traditional taxa (areas-as-taxa) and taxa distribution serves as characters (taxa-as-characters). The areas used are inserted as "operational geographic units" (OGUs). PAE can be evaluated by entering OGUs in three different ways: localities (Rosen, 1988), previously delimited areas (Cracraft, 1991; Morrone and Crisci, 1995), or quadrats (Morrone, 1994). Currently, PAE has also been used to detect areas of endemism (e.g. Silva and Oren, 1996; Linder, 2001). Unlike cladistic biogeography, PAE does not require an existing phylogeny of the studied group (Rosen, 1988; Glasby and Alvarez, 1999). The main concern of this approach is the history of areas or localities, and it cannot prove or reveal any information about processes.

The Terebellidae, one of the most diverse groups within the polychaetes, has a worldwide distribution, occurring from shallow to deep waters. The family comprises more than 450 species grouped in 4 sub- families, Terebellinae, Polycirrinae, Thelepodinae, and Trichobranchinae (Rouse and Pleijel, 2001), though conflicting views on its taxonomical status were presented by Hutchings (2000), Colgan et al. (2001), Rousset et al. (2003), Garraffoni and Lana (2004a), and Glasby et al. (2004).

In contrast to the excellent taxonomic analyses provided by Hessle (1917), Fauvel (1927), Hutchings (1977, 1990, 1997a,b), Hutchings and Glasby (1986a,b,c, 1987, 1988, 1990), and Holthe (1986a), biogeographic information on Terebellidae is still scarce. This holds true for other polychaete (e.g. Glasby, 1999) or marine groups (e.g. Hajdu, 1998). The only biogeographical study available for the group was carried out on the terebellids of Australia by Hutchings and Glasby (1991), who did not use any testable explicit analytical biogeographic methodology.

The present paper analyses the distribution patterns of Terebellidae from worldwide coastal and continental shelf areas using PAE. The null hypothesis to be tested is that no areas of endemism exist for Terebellidae derived from the splitting of Pangaea into Laurasia and Gondwana. This testable hypothesis can be usefully compared with other marine groups in order to delineate more large-scale historical patterns across several different taxa (de Grave, 2001).

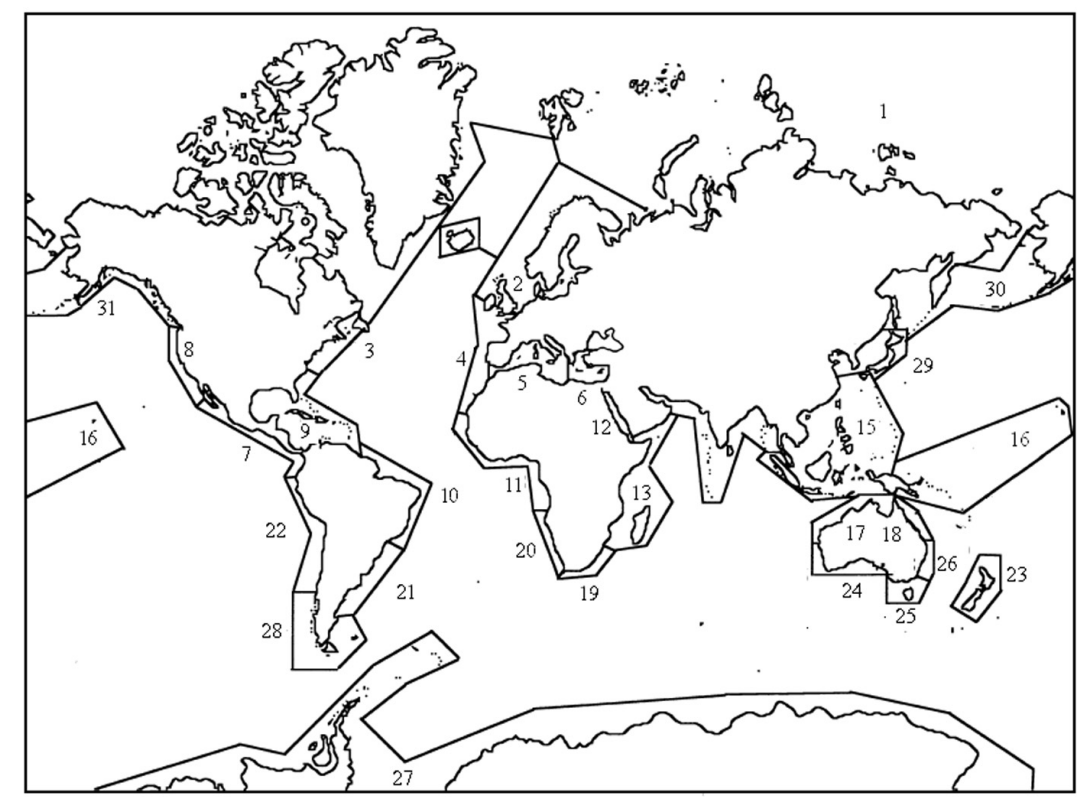

FIG. 1. - Areas of endemism, numbered 1-30, used in the present study (modified from van Soest and Hajdu, 1997; Glasby and Alvarez, 1999). 1, Arctic; 2, Boreal Eastern Atlantic; 3, Boreal Western Atlantic; 4, Northeastern Atlantic; 5, Western Mediterranean; 6, Eastern Mediterranean; 7, Californian; 8, Western Pacific; 9, Caribbean; 10, Brazilian; 11, Western Africa; 12, Red Sea; 13, Western Indian Ocean; 14, Central Indian Ocean; 15, Indo-Malaysian; 16, Central Pacific; 17, Northwestern Australian; 18, Northeastern Australian; 19, Southern Africa; 20, Southwestern Africa; 21, Southwestern Atlantic; 22, Chilean; 23, New Zealander; 24, Southwestern Australian; 25, Southeastern Australian; 26, Tasmanian; 27, Antarctic; 28, Magellanic; 29, Japan-China Sea; 30, Boreal Pacific. 


\section{MATERIAL AND METHODS}

\section{Areas of endemism}

Following Craw (1988), Cracraft (1991), Morrone (1998) and Glasby and Alvarez (1999), we delimited the areas of endemism prior to analysis. These areas of endemism should contain at least two species having more or less congruent distribution limits (Platnick, 1991). Thus, 30 areas of endemism (Fig. 1), or OGUs, were recognized following similar studies on marine invertebrates (van Soest and Hajdu, 1997; Hajdu, 1998; Glasby, 1999). The resulting data set (available upon request to the authors or at http://www.cem.ufpr.br/garraffoni/ paedollo.nex) was analysed with PAE methodology (Rosen, 1988; Platnick, 1991) using Dollo parsimony. This kind of parsimony allows for any given taxon to appear only once, but to be lost as many times as necessary.

\section{Choice of taxa}

The resulting data set was restricted in its range to coastal areas, and the continental shelf. We excluded the deep sea areas because terebellids are poorly known in these environments and because the deep ocean represent an impassable barrier to most shelf species (Glasby and Alvarez, 1999). In addition, different evolutionary pressures may operate on deepsea taxa and it would be difficult to establish the boundaries between one potential OGU and another. For the present analysis we have chosen representatives of all of the 62 valid genera and a large set of 208 species. Not all species were included, as those exclusive to a single area are not useful for the analysis as they do not provide evidence of relationships between areas (Glasby and Alvarez, 1999; Enghoff, 2000). We also coded genera concomitantly to species, whenever a given genus had more than one species present in the distinct areas (Platnick, 1991; Glasby and Alvarez, 1999). This solution was used 36 times in the analysis. As suggested by Glasby and Alvarez (1999), we excluded the cosmopolitan species a priori, because it is difficult to confirm whether a reported cosmopolitanism is a natural pattern or the result of inadequate sampling or taxonomic artifacts. Many terebellid species previously presumed to be cosmopolitan have been recently split or described as new (e.g. Williams, 1984; Hutchings and Glasby, 1986a, b, c; Hutchings and Peart, 2000; SolisWeiss et al., 1991).
Data on the distribution of species were gathered from monographs, reviews and checklists, since it would be impossible to identify or check all relevant material (Malmgren, 1866; Hessle, 1917; Fauvel, 1927; Monro, 1936; Day, 1955, 1967; Hartman, 1955, 1965, 1966; Imajima and Hartman, 1964; HartmannSchröder, 1965; Knox and Cameron, 1971; Kritzler, 1971; Hutchings, 1977, 1990, 1993, 1997a,b; Hutchings and Glasby 1986a, b, c, d, 1987, 1988, 1991, 1995; Banse, 1980; Kingston and Mackie, 1980; Williams, 1984; Imajima and Williams, 1985; Holthe, 1986a, b; Blankensteyn and Lana, 1987; Solis-Weiss et al., 1991; Hutchings and Smith, 1997; Hutchings and Peart, 2000; Nogueira and Amaral, 2001; Nogueira et al., 2003; Garraffoni and Lana, 2003).

\section{Data matrix analysis}

The analysis was carried out using Nexus Data Editor (Page, 2001) for editing the data matrix, and Phylogenetic Analysis Using Parsimony (PAUP 4.0 beta10) (Swofford, 2001) for heuristic tree searches, with 100 replicates, using closest stepwise addition sequence, zero-length branches were collapsed, and MULPARS was activated. Taxa were coded as absent (0) or present (1) in each area within the data matrix (http://www.cem.ufpr.br/garraffoni/paedollo.nex). The ancestral area of the cladogram was rooted using a hypothetical area coded with zeros.

\section{RESULTS}

\section{Levels of endemicity}

Based on the condensed OGUs, Terebellidae exhibit a high degree of endemicity (Table 1), with nearly half of the studied species occurring in only one of the areas. At the other end of the scale, a maximum of five areas were shared by only $5.4 \%$ of all species. Our results closely resemble those of Glasby and Alvarez (1999) who investigated the distribution of austral Polychaeta based on taxa of Eunicidae, Lumbrineridae, Oenonidae, Onuphidae, Serpulidae and Spionidae.

We observed that the level of endemism at the species level is $44.4 \%$ or, in other words, that 92 species are found only in one area (Table 1). This number is low if compared to the results obtained by Glasby and Alvarez (1999). In that analysis, the authors obtained over $60 \%$ of the studied species 
TABLE 1. - Level of endemism among terebellid species in the 30 worldwide areas used in this paper.

\begin{tabular}{lr}
\hline $\begin{array}{l}\mathrm{N}^{\circ} \text { of areas for which } \\
\text { species is endemic }\end{array}$ & $\mathrm{N}^{\circ}$ of species. (\% of total) \\
\hline 1 area & $92(44.4 \%)$ \\
2 areas & $53(25.6 \%)$ \\
3 areas & $32(15.5 \%)$ \\
4 areas & $19(9.2 \%)$ \\
5 areas & $11(5.4 \%)$ \\
Total & 208 \\
\hline
\end{tabular}

occupying a single area of endemism. Boreal Western Atlantic, Northwestern Atlantic and Tasmanian areas exhibited lowest levels of endemism, with only one endemic species each, whilst Southeastern Australian areas and Antarctic areas exhibited the highest endemism levels, with nine endemic species (Table 2 ). The great endemicity presented by the Southeastern Australian area was expected (Table 2), as a result of the amount of work done in this area compared with other regions. A similar pattern was independently demonstrated for other polychaete groups (Hutchings, 1974; Hutchings et al., 1978; Hutchings and Rainer, 1979a,b; Hutchings and Murray, 1984; Hutchings and Glasby, 1986a,b, 1987, 1988, 1991; Hutchings and Smith, 1997; Hutchings and Peart, 2000).

\section{PAE}

A total of 208 taxa were included in the analysis, representing about $55 \%$ of all known terebellid

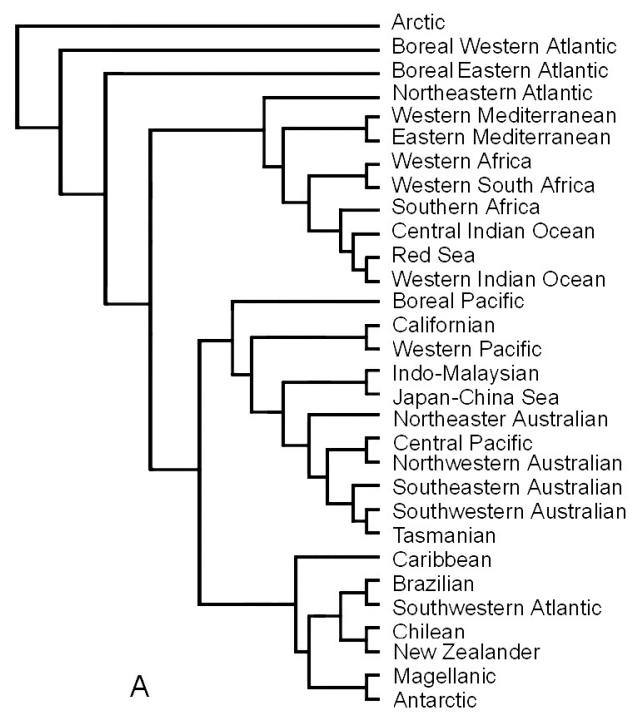

TABLE 2. - Species endemism in the 30 worldwide areas, showing number of endemic species and percentage of total.

\begin{tabular}{ll}
\hline Endemism Area & $N^{\circ}$ of endemic species \\
\hline Southeastern Australian & \\
Antarctic & $9(9.7 \%)$ \\
Japan-China Sea & $9(9.7 \%)$ \\
Caribbean & $8(8.6 \%)$ \\
Northeastern Australian & $7(7.5 \%)$ \\
Boreal Eastern Atlantic & $6(6.5 \%)$ \\
Californian & $5(5.4 \%)$ \\
Western Pacific & $5(5.4 \%)$ \\
Northwestern Australian & $5(5.4 \%)$ \\
Southeastern Atlantic & $5(5.4 \%)$ \\
Chilean & $5(5.4 \%)$ \\
Central Indian Ocean & $5(5.4 \%)$ \\
Southern African & $4(4.3 \%)$ \\
Indo-Malaysian & $4(4.3 \%)$ \\
New Zealander & $3(3.2 \%)$ \\
Western África & $3(3.2 \%)$ \\
Red Sea & $2(2.1 \%)$ \\
Western Indian Ocean & $2(2.1 \%)$ \\
Boreal Western Atlantic & $2(2.1 \%)$ \\
Northwestern Atlantic & $1(1.9 \%)$ \\
Tasmanian & $1(1.9 \%)$ \\
\end{tabular}

species occurring around the world. Despite the fact that 96 species were of no value for the analysis, the final number of informative species (108) is greater than the 80 minimum number of taxa proposed by Glasby and Alvarez (1999) for satisfactory results for groups displaying similar distributional characters.

Under Dollo parsimony, two most parsimonious cladograms (Fig. 2), almost identical in topology and of 696 steps length were generated, consistency index $(\mathrm{CI})=0.351$, and retention index $(\mathrm{RI})=0.881$. The only difference between the two cladograms relates to the placement of the Boreal Western Atlantic areas. In one of the cladograms (Fig. 2A),

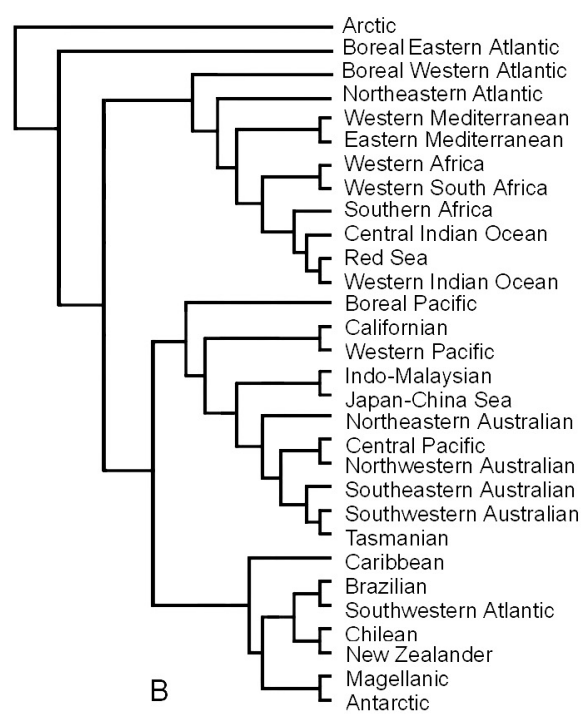

FIG. 2. - Two equally parsimonious PAE cladograms under the assumption of no dispersal (Dollo parsimony) for 30 areas of endemism. 
Boreal Western Atlantic is placed as a sister-group of Boreal Eastern Atlantic and all the remaining endemic areas. In the other cladogram (Fig. 2B), Boreal Western Atlantic is only a sister-group of the clade areas (Northeastern Atlantic ((Western Mediterranean, Eastern Mediterranean) (((Western Africa, Western South Africa) ((((Southern Africa) $((((($ Central Indian Ocean) $)((()($ Red Sea, Western Indian Ocean)) )))).

In both cladograms, most of the apical clades were formed by Gondwana areas (Caribbean ((Magellanic, Antarctic) (((Brazilian, Southwestern Atlantic) $\quad((($ Chilean, New Zealander $))))$ or ((Northeastern Australian) (((Central Pacific, Northwestern Australian) ((((Southeastern Australian) ((()(Southwestern Australian, Tasmanian))))))), and basal clades were formed by Laurasian areas. However, we did not observe a complete or expected division between Gondwana and Laurasian clades.

\section{DISCUSSION}

\section{Limitation of the study}

Though we have mostly used the literature produced by specialists on terebellids to distinguish distribution patterns, we are aware of the limitations of the published data. As such, the biogeographical patterns discussed hereafter are totally dependent on the accuracy of these identifications.

As argued by Glasby and Alvarez (1999) and de Grave (2001), the degree of dispersal capabilities and the taxa choice impose two main limitations in PAE analysis. Glasby and Alvarez (1991) reported that species known to have planktonic development should be excluded, since their larvae can stay in the water column for long periods, thus resulting in widespread adult distributions.

Reproductive and development traits have so far been studied in 20-25 terebellid species (Garraffoni and Lana, 2004b), and only the genera Loimia and Lanice have larvae that can survive for long periods (months or even years) in the plankton (Bhaud, 1988; McHugh, 1993; Garraffoni and Lana, 2004b). The other genera studied (e. g. Thelepus, Trichobranchus, Terebellides, Neoleprea, Neoamphitrite, Nicolea, Eupolymnia, Amphitrite, Amaena) have lecithotrophic or direct development. Thus, the assumption that widespread adult distributions result from planktonic development cannot be an important factor in the present study,

Another potential problem is that the available information on the taxonomy and distribution patterns of the chosen groups varies greatly amongst areas. For instance, polychaete faunas of South Africa, Australia, North Sea, and eastern North America are better known on account of previous surveys (Hessle, 1917; Hartman, 1955, 1965; Day, 1967; Holthe, 1986a, b; Hutchings, 1977, 1990, 1993, 1997a; Hutchings and Glasby, 1986a, b, c, 1987, 1988, 1991, 1995). On the other hand, other areas used in this study are less well-known, such as the South American and African coasts.

Cracraft (1991), Glasby and Alvarez (1991) and de Grave (2001) also emphasized the unfortunate PAE characteristic of being unable to utilize the biogeographic information provided by the taxa occurring in a single endemism area. However, as only partial phylogenetic analyses of terebellids are available as yet (McHugh 1995; Glasby et al., 2004), PAE is the only current testable methodology which can be used to study and describe distribution patterns.

\section{Hierarchical patterns}

The distribution patterns (Figs. 2 and 3) show a hierarchical pattern in which the Northern Hemisphere areas are the most basal, whereas the land masses which once formed the Gondwana supercontinent are predominantly the most apical ones. These clearly defined African, South American-Antarctic and Australian clades are independently rooted by Laurasian components.

Based upon the results from PAE analysis, the hierarchical pattern obtained for Terebellidae could be preliminarily interpreted as that much of extant terebellid worms occurring in the Southern Hemisphere have originated from Northern Hemisphere ancestors or, in the case of the clade formed by Caribbean, Brazilian, etc., they have descended directly from an ancestral lineage common to some Northern areas. The PAE cladogram also indicates that the Euro-American areas (e.g. Boreal Atlantic, Northeastern Atlantic, Mediterranean) are more primitive than the Asian, Australasian or South American ones.

Unfortunately, as polychaetes generally do not fossilize well, fossil records are very scarce and this is especially true for terebellids. Thomas and Smith 


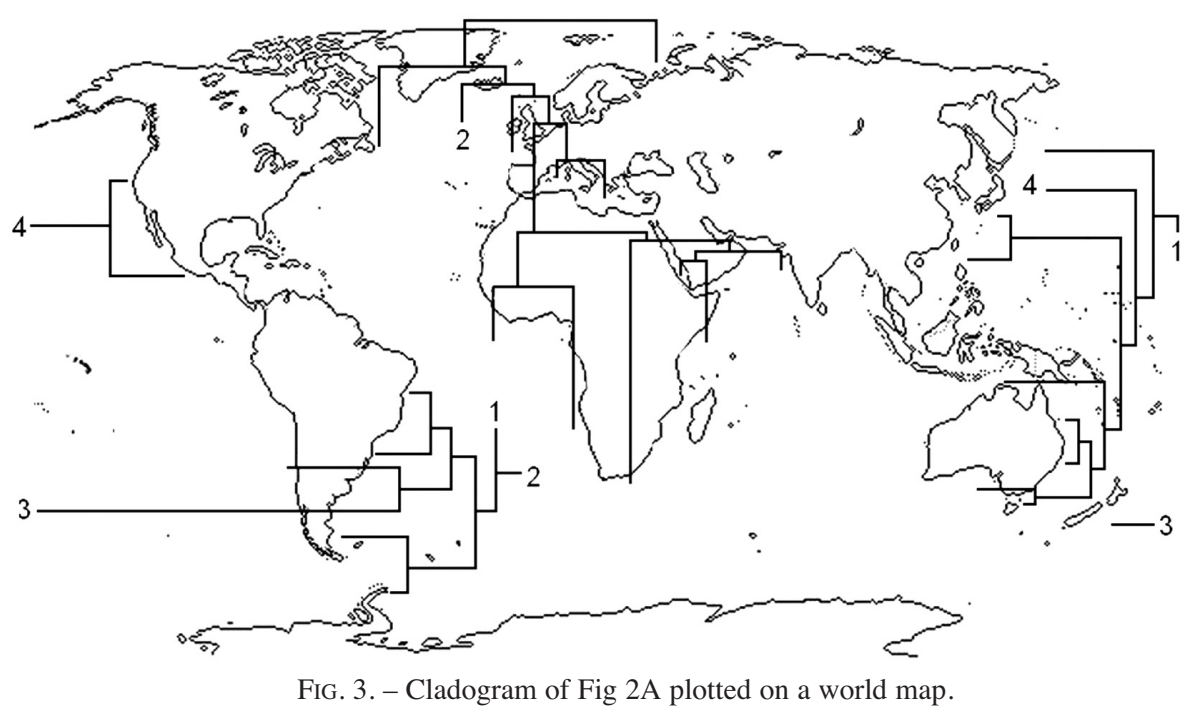

(1998) described a Silurian terebellid fossil from England and Canada. Previously, Thomson (1979) had described the oldest known fossil of Flabelligeridae (a taxon within the clade Terebellida, according to Rouse and Pleijel, 2001, but see Hall et al., 2004 and Glasby et al., 2004) from Australia, with its approximate age estimated to be Devonian. Hay (2002) studied flabelligerid fossils from the Francis Creek shale of Illinois estimated to date from Late Carboniferous. Fossilized tubes found in the Erins Vale Formation (Australia), from the Late Permian, have been identified by Pickett (1972) as probably belonging to Terebellidae.

Despite the scarcity of fossil data, the available information corroborates the hierarchical pattern provided by the PAE cladogram. The Silurian record (Thomas and Smith, 1998) from England and Canada is a faunal indicator of the great extent of the Euramerican continent in past times. In the same way, the distribution pattern based on extant terebellids show that North American and European areas are closely related, and that they are at the base of the clade including African and Indian areas. Another interesting point is the close relationship between Indo-Malaysian, Japan-China Sea and the Australasian areas. This is highly congruent with geological maps reconstructed and hypothesized for the Devonian, Silurian and Pre-Silurian times (Hallam, 1994), in which both Southeastern and Far Eastern Asia were in close contact with the Australasian mainland and landmasses.

In accordance with the interpretation that terebellids originated from an Euro-American lineage and later diversified throughout the Southern Hemisphere, there are some terebellid genera shar- ing a common distribution pattern, namely Axionice, Baffinia, Laphania, Leaena, Neoamphitrite, Nicolea, and Scionella. All of them are distributed in Euroamerica, Southeastern and Far Eastern Asia and Australasia, and their current distribution patterns suggest that they are probably faunal indicators of the geological history of those areas.

Although congruent with geological data, our results do not agree with the patterns described for sponges by Hajdu (1995) and van Soest and Hajdu (1997). In the first study, the author applied Brooks Parsimony Analysis, PAE and track analysis (Panbiogeography), and obtained general area cladograms indicating a possible Gondwanan origin for most tropical marine sponges. In the same way, the experimental results of van Soest and Hajdu (1997) by submitting a common distributional data source to different methodologies (Brooks Parsimony Analysis, Component Analysis and Three-Area Statements Analysis) and coding strategies ("Assumption 0" and "No Assumption") were mostly concordant with Hajdu (1995). Fauchald (1984) pointed out the possible incongruence of the geographical pattern shown by polychaetes at the family level with any group that did not evolve until the Mesozoic or Cenozoic, since most of the polychaete taxa were present already in the Palaeozoic.

The high-level patterns (general trends) described by Hajdu (1995) and van Soest and Hajdu (1997) clearly differ from ours, though some specific area relationships are rather similar. The same applies to the results of Hajdu (1998) who exclusively used pan-biogeographic tools and obtained some particular trends in sponges quite similar to some shown by terebellids. The general patterns 
described by Hajdu (1998: 100, fig. 3) resemble Terebellidae-based biogeographical patterns in relation to the sister-group relationships between the OGUs Brazilian+Southwestern Atlantic, JapanChina Sea and Indo-Malaysian, and Northeastern Atlantic and Western and Eastern Mediterranean. Similarly, De Grave (2001) using PAE for a group of shrimps (Pontoniinae) also found a close relationship between the Indo-Pacific areas. The results obtained by Glasby and Alvarez (1999) for austral polychaetes are of limited use for comparative purposes since that paper only included areas belonging to the Austral domain, namely Southern Africa, Southern America, Antarctica, Australia, New Zealand and other correlated areas.

The terebellid-based biogeographic patterns described herein were mainly compared with other marine invertebrate groups, as no other world-wide polychaete studies are available as yet. More reliable biogeographic interpretations will only be possible when a comprehensive phylogenetic hypothesis of terebellids as a whole becomes available.

\section{ACKNOWLEDGEMENTS}

We are much indebted to Eduardo Hajdu, Pat Hutchings and two anonymous reviewers for advice and comments. This research was supported by a grant provided to the first author by the Brazilian funding agency CAPES.

\section{REFERENCES}

Banse, K. - 1980. Terebellidae (Polychaeta) from the Northeast Pacific Ocean. Can. J. Fish. aquat. Sci., 37: 20-40.

Bhaud, M. - 1988. The two planktonic larval periods of Lanice conchilega (Pallas, 1766) Annelida Polychaeta, a peculiar example of the irreversibility of evolution. Ophelia, 29: 141-152.

Blankensteyn, A. and P.C. Lana.-1987. Octobranchus longipes sp. n. (Trichobranchidae: Polychaeta) da costa sudeste do Brasil. Arq. Biol. Tec., 30: 671-676.

Colgan, D., P.A Hutchings and S. Brown. - 2001. Phylogenetic relationships within the Terebellomorpha. J. Mar. biol. Ass. U.K., 81: 765-773.

Cracraft J. - 1991. Pattern of diversification within continental biotas: hierarchial congruence among the areas of endemism of Autralian vertebrates. Aust. Syst. Bot., 4: 211-227.

Craw, R.C. - 1988. Continuing the synthesis between panbiogeography, phylogenetic systematics and geology as illustrated by empirical studies on biogeography of New Zealand and the Chatham Island. Syst. Zool., 37: 291-310.

Day, J.H. - 1955. The Polychaeta of South Africa. Part 3. Sedentary species from Cape shores and estuaries. J. Linn. Soc. London, 42: 407-452.

Day, J.H. - 1967. A monograph on the Polychaeta of Southern Africa. Part. 2 Sedentaria. British Museum of Natural History, London. de Grave, S. - 2001. Biogeography of Indo-Pacific Pontoniinae (Crustacea, Decapoda): a PAE analysis. J. Biogeogr., 28: $1239-1253$.

Enghoff, H. - 2000. Revels as branch support in Biogeography parsimony analysis. Vie Milieu, 4: 255-260.

Fauchald, K. - 1984. - Polychaete distribution patterns, or : can animals with Palaeozoic cousins show large-scale geographical patterns. In: P.A. Hutchings (ed.), Proceedings of the First International Polychaete Conference, Sydney, pp. 1-6. The Linnean Society of New South Wales.

Fauvel, P. - 1927. Faune de France vol. 16. Polychètes sédentaires. Addenda aux Errantes, Archiannélides, Myzostomaires. Librairie de la Faculté des Sciences Paul Lechevalier, Paris.

Garraffoni, A.R.S. and P.C. Lana. - 2003. Species of Terebellides (Polychaeta, Terebellidae, Trichobranchinae) from the Brazilian coast. Iheringia, 93: 355-363.

Garraffoni, A.R.S. and P.C. Lana. - 2004a. - Cladistic analysis of the subfamily Trichobranchinae (Polychaeta, Terebellidae). $J$. Mar. biol. Ass. U.K., 84: 973-982.

Garraffoni, A.R.S. and P.C. Lana. - 2004b. Life histories of Terebellidae (Polychaeta: Annelida) as a basis for phylogenetic analyses. In: Abstract to the $10^{\text {th }}$ International Congress on Invertebrate Reproduction and Development, Newcastle, p. 27.

Glasby, C.J. - 1999. The Namanereidinae (Polychaeta: Nereididae) Part 2, Cladistic Biogeography. Rec. Aust. Mus., 25: 131-144.

Glasby, C.J and B. Alvarez. - 1999. Distribution patterns and biogeographic analysis of Austral Polychaeta (Annelida). J. Biogeogr., 26: 507-533.

Glasby, C.J, P.A Hutchings, and K. Hall - - 2004. Assessment of monophy and taxon affinities within the polychaete clade Terebelliformia (Terebellidae). J. Mar. biol. Ass. U.K., 84: 961-971.

Hajdu, E. - 1995. Macroevolutionary patterns within the demosponge order Poecilosclerida: phylogeny of the marine cosmopolitan genus Mycale, and an integrated approach to biogeography of the seas. $\mathrm{PhD}$. Thesis, Universiteit van Amsterdam.

Hajdu, E. - 1998. Toward a panbiogeography of the seas: sponge phylogenies and general tracks. In: Y. Watanabeand and N. Fusetani (eds), Sponge Sciences, multidisciplinary perspectives, Proceedings of International Conference on Sponge science, pp. 25-39. Japan.

Hall, KA., PA Hutchings and D.J. Colgan. - 2004. Further phylogenetic studies of the Polychaeta using rDNA sequence data. $J$. Mar. biol. Ass. U.K., 84: 949-960.

Hallam, A. - 1994. An outline of Phanerozoic biogeography. Oxford Biogeography Series n. 10, Oxford University Press.

Hartman, O. - 1955. Quantitative survey of the benthos of San Pedro Basin. Southern California. Part III. Systematic: Polychaeta. Allan Hancock Pacific Exped., 27: 1-86.

Hartman, O. - 1965. Catalogue of the polychaetous annelids of the World. Supplement 1960-1965 and index. Occ. Pap. Allan Hancock Fdn., 23: 1-197.

Hartman, O. - 1966. Polychaeta Myzostomidae and Sedentaria of Antarctica. Antarctic Res. Ser., 3: 1-131.

Hartmann-Schröder, G. - 1965. Die Polychaeten des Sublitorals. In: G. Hartmann-Schröder and G. Hartmann. Zur Kenntnis des Sublitorals der chilenischen Küste unter besonderer Berücksichtigung der Polychaeten und Ostracoden. Mitt. hamb. zool. Mus. Inst., 62: 59-305.

Hay, A.A. - 2002. Flabelligerida from the Francis Creek shale of Illinois. J. Paleontol., 76: 764-766.

Hessle, C. - 1917. Zur Kenntnis der terebellomorphen Polychaeten. Zool. Bidr. Upps, 5: 39-258.

Holthe, T. - 1986a. Polychaeta Terebellomorpha. Marine Invertebrates of Scandinavia. vol. 7. Norway: Norwegian University.

Holthe, T. - 1986b. Evolution, systematics and distribution of the Polychaeta Terebellomorpha, with a catalogue of the taxa and a bibliography. Gunneria, 55: 1-236.

Hutchings, P.A. - 1974. Polychaeta of Wallis Lake, New South Wales. Proc. Linn. Soc. N. S. W., 98: 195-195.

Hutchings, P.A. - 1977. Terebelliform Polychaeta of the families Ampharetidae, Terebellidae and Trichobranchidae from Australia, chiefly from Moreton Bay, Queensland. Rec. Austr. Mus., 31: 1-38.

Hutchings, P.A. - 1990. Terebellidae (Polychaeta) from the Hong Kong region. In: B. Moreton (ed.), Proceedings of the Second 
International Workshop on the Marine Flora and Fauna of Hong Kong and Southern China, pp. 377-412. University of Hong Kong.

Hutchings, P.A. - 1993. New species of the family Terebellidae (Polychaeta) from Rottnest Island, Western Australia. In: F.E. Wells, D.I. Walker, H. Kirkman and R. Lethbridge (eds.), Proceedings of the 5th International Marine Biological Workshop. The Marine Flora and Fauna of Rottnest Island, Western Australia, pp. 321-330.

Hutchings, P.A. - 1997a New species of the family Terebellidae (Polychaeta) from Darwin Harbour Australia. In: R. Hanley (ed.), Proceedings of the 6th International Marine Biological Workshop, pp. 133-161.

Hutchings, P.A. - 1997b. New species of the family Terebellidae (Polychaeta) from Abrohlos Island, Western Australia. In: F.E. Wells. (ed.), Proceedings of the 7th International Marine Biological Workshop. The Marine Flora and Fauna of Abrolhos Island, Western Australia, pp. 459-502.

Hutchings, P. - 2000. Family Trichobranchidae. In P.L. Beesley, G.L.B. Ross and C.J. Glasby (eds.), Polychaeta \& Allies: The Southern Synthesis. Fauna of Australia. Vol. 4a Polychaeta, Myzostomida, Pogonophora, Echiura, Sipuncula. Melbourne: CSIRO.

Hutchings, P.A. and C.J. Glasby. - 1986a. A revision of the genus Euthelepus (Terebellidae: Polychaeta). Rec. Austr. Mus., 38: 105-117.

Hutchings, P.A. and C.J. Glasby. - 1986b. The Polycirrinae (Polychaeta: Terebellidae) from Australia. Rec.Austr. Mus., 38: 319-350.

Hutchings, P.A. and C.J. Glasby. - 1986c. Glossothelepus, a new genus (Polychaeta: Terebellidae) from the Gulf of California, Mexico. Proc. Biol. Soc. Wash., 99: 84-87.

Hutchings, P.A. and C.J. Glasby. $-1986 \mathrm{~d}$. A revision of the genus Euthelepus (Terebellidae: Thelepinae). Rec. Austr. Mus., 38: 105-117.

Hutchings, P.A. and C.J. Glasby. - 1987. The Thelepinae from Australia, with a discussion of the generic and specific characters of the family. Bull. Biol. Soc. Wash., 7: 217-250.

Hutchings, P.A. and C.J. Glasby. - 1988. The Amphitritinae (Polychaeta: Terebellidae) from Australia. Rec. Austr. Mus., 40: 1-60.

Hutchings, P.A. and C.J. Glasby. - 1990. Additional new species of F. Terebellidae (Polychaeta) from Western Australia, with a key to all described species from the region. In: F.E. Wells, D.I. Walker, H. Kirkman and R. Lethbridge (eds), The Flora and Fauna of the Albany Area, Western Australia. pp. 251-289.

Hutchings, P.A. and C.J. Glasby. - 1991. Phylogenetic implications of the biogeography of Australian Terebellidae (Polychaeta). Ophelia, 5: 565-572.

Hutchings, P.A. and C.J. Glasby. - 1995. Description of the widely reported terebellid polychaetes Loimia medusa (Savigny) and Amphitrite rubra (Risso). Mitt. Hamb. zool. Mus. Inst., 92: 149-154.

Hutchings, P.A., P.I. Nicol and A.K. O'Gower. - 1978. The marine macrobenthic communities of Wallis and Smiths Lakes, New South Wales. Aust. J. Ecol. 3: 79-90.

Hutchings, P.A. and A. Murray. - 1984. Taxonomy of polychaetes from the Hawkesbury River and the southern estuaries of New South Wales, Australia. Rec. Aust. Mus., 36: 1-119.

Hutchings, P.A. and R. Peart. - 2000. A revision of the Australian Trichobranchidae (Polychaeta). Invertebr. Taxon., 14: 225-272.

Hutchings, P.A. and S.F. Rainer. - 1979a, The polychaete fauna of Careel Bay, Pittwater, New South Wales, Australia. J. nat. Hist., 13: 745-795.

Hutchings, P.A. and S.F. Rainer. - 1979b. A key to estuarine polychaetes in New South Wales. Proc. Linn. Soc. N. S. W., 104: 35-48.

Hutchings, P.A. and R. Smith. - 1997. Descriptions of new species and comments on previously described species of terebellid polychaetes from New Zealand and Australia. Bull. Mar. Sci., 60: 324-349.

Imajima, M. and O. Hartman. - 1964. The polychaetous annelids of Japan. Part II. Occ. Pap. Allan Hancock Fdn., 26: 1-452.

Imajima, M. and S.J. Williams. - 1985. Trichobranchidae (Polychaeta) chiefly from the Sagami and Suruga Bays, collected by R/V Tansei Maru (Cruises KT-65-76). Bull. Natn. Sci. Mus., Tokyo, Ser. A, 11: 7-18.

Kingston, P.F. and A.S.Y. Mackie. - 1980. Octobranchus floriceps sp. nov. (Polychaeta: Trichobranchidae) from the northern
North Sea with a re-examination of $O$. antarcticus Monro. Sarsia, 65: 249-254.

Knox, G.A. and D.B. Cameron. - 1971. Port Phillip survey Pt 2.4. Polychaeta. Mem. National Mus., 32: 21-41.

Kritzler, H. - 1971. Observations on a new species of Streblosoma from the northeast Gulf of Mexico (Polychaeta, Terebellidae). Bull. Mar. Sci., 21: 904-913.

Linder, H.P. - 2001. On areas of endemism, with an example from the African Restionaceae. Syst. Biol., 50: 892-912.

Malmgren, A.J. - 1866. Nordiska Hafs-Annulater. Öfvers. K. VetenskAkad. Stockh. Förh, 22: 335-410.

McHugh, D. - 1993. A comparative study of reproduction and development in the Polychaeta family Terebellidae. Biol. Bull., 185: $153-167$.

Monro, C.C.A. - 1936. Polychaete worms. II. Discovery Rep., 12: 59-198.

Morrone, J.J. - 1994. On the identification of area of endemism. Syst. Biol., 3: 438-441.

Morrone, J.J. - 1998. On Udvardy's Insulantarctica province: a test from the weevils (Coleoptera: Curculionoidea). J. Biogeogr., 25: $947-955$.

Morrone, J.J. - 2001. Homology, biogeography and areas of endemism. Diver. Distrib., 7: 297-300.

Morrone, J.J. and J.V. Crisci. - 1995. Historical biogeography: introduction to methods. Annu. Rev. Ecol. Syst., 26: 373-401.

Nogueira, J.M.M. and A.C.Z Amaral. - 2001. New terebellids (Polychaeta: Terebellidae) associated with a stony coral in São Paulo State, Southeastern Brazil. Proc. Biol. Soc. Wash., 114: 297-308.

Nogueira, J.M.M, Hutchings, P.A. and A.C.Z. Amaral. - 2003. Articulatia, a new genus of Terebellinae (Polychaeta: Annelida) living in Brazil coral. J. Mar. Biol. Ass. U.K., 83: 761-770.

Page, R.D.M. - 2001. NDE (Nexus Data Editor), version 0.5.0. Program distributed by the author.

Pickett, J.W. - 1972. The ecology of worm populations in the Erins Vale formation (Late Permian) southern Sydney basin. J. Geol. Soc. Aust., 19: 313-320.

Platnick, N.I. - 1991. On areas of endemism. In: P.Y. Ladiges, C.J. Humphries and I.W. Martinelli (eds.), Austral biogeography, prefacio (no pagination). Melbourne, CSIRO.

Rousset, V., G.W. Rouse, J.P. Feral, D. Desbruyères and F. Pleijel. - 2003. Molecular and morphological evidence of Alvinellidae relationships (Terebelliformia, Polychaeta, Annelida). Zool. Scr., 32, 185-197.

Rouse, G.W. and P. Pleijel. - 2001. Polychaetes. London: Oxford.

Rosen, B.R. - 1988. From fossils to earth history: applied historical biogeography. In: A.A. Myers and P.S. Giller (eds.), Analytical biogeography: an integrated approach to the study of animal and plant distribution, pp 437-481. Chapman and Hall. London.

Silva, J.M.C. and D.C. Oren. - 1996. Application of parsimony analysis of endemicity in Amazonian biogeography: an example with primates. Biol. J. Linn. Soc., 59: 427-437.

Solis-Weiss, V., K. Fauchald and A. Blankensteyn. - 1991. Trichobranchidae (Polychaeta) from shallow warm water areas in the Western Atlantic Ocean. Proc. Biol. Soc. Wash., 104: 147-158.

Swofford, D.L. - 2001. PAUP: Phylogenetic Analysis Using Parsimony, Version 4.0 betal0. Computer program and manual distributed by Center de biodiversity, Illinois Natural History Survey, Champaign, Illinois.

van Soest, R.W.M. and E. Hajdu. - 1997. Marine area relationships from twenty sponge phylogenies. A comparison of methods and coding strategies. Cladistics, 13: 1-20.

Thomas, A.T. and M.P. Smith. - 1998. Terebellid polychaete burrows from the Lower Palaeozoic. Paleontology, 41: 317-333.

Williams, S.J. - 1984. The status of Terebellides stroemii (Polychaeta: Trichobranchidae) as a cosmopolitan species, based on a worldwide morphological survey, including description of new species. In: P.A. Hutchings (ed.), Proceedings of the First International Polychaete Conference, Sydney, pp. 118-142. The Linnean Society of New South Wales.

Received September 14, 2004. Accepted May 11, 2005. 